\title{
Muzealizacja przestrzeni publicznej jako forma obecności dziedzictwa kulturowego we współczesnym społeczeństwie
}

\author{
Andrzej Kadłuczka \\ Politechnika Krakowska, Wydział Architektury, Kraków, Polska
}

\begin{abstract}
Streszczenie: W artykule omówiono nowe zjawisko muzealizacji przestrzeni publicznej, które nie oznacza jedynie dostrzeganego przez socjologów dynamicznie wzrastającego zapotrzebowania społecznego na innowacyjnie i atrakcyjnie kształtowane muzea, czy centra promocji dziedzictwa historycznego, ale także coraz szersza, bezpośrednią - „fizyczną” obecność tego dziedzictwa w życiu współczesnego człowieka. Jest ta obecność generowana poprzez inwestycje realizowane na terenach historycznych, które stają się źródłem coraz większej ilości struktur i artefaktów pochodzących z przeszłości „zasiedlających” przestrzeń publiczną w formie niej lub bardziej udanych ekspozycji rekonstruujących rzeczywistość historyczną.

Słowa kluczowe: przestrzeń, przestrzeń publiczna, dziedzictwo kulturowe, muzeum, ekomuzeum, muzealizacja.
\end{abstract}

\section{Przestrzeń a przestrzeń publiczna}

Na pytanie czym jest przestrzeń? Rudolf Arnheim podaje na początku prostą odpowiedź: „,przestrzeń to niezależny byt, skończony badź nie skończony" ", ale dalej dodaje, że jest to definicja wyjściowa mówiąca o formie bytu poprzedzającej pojawienie się w tej przestrzeni rzeczy ją zasiedlających - ,przedmiotów w niej istniejacych”. I wtedy dopiero możemy mówić o problemie percepcji tej przestrzeni, która to percepcja może zaistnieć „tylko wtedy, kiedy mamy do czynienia z dajacymi się postrzegać rzeczami”. Co więcej, doświadczenie w percepcji przestrzeni powstaje ,jedynie dzięki wzajemnym relacjom zachodzacym pomiędzy przedmiotami"2.

Rozważania Arnheima na temat przestrzeni w ogóle są kluczowe także dla zrozumienia mechanizmów kształtowania przestrzeni, która jest „stworzona za pomoca pewnego specyficznego układu przedmiotów naturalnych oraz wytworzonych przez człowieka" " ${ }^{3}$

W tym przypadku, kiedy w grę wchodzi działalność człowieka i przestrzeń jest „zasiedlana" rzeczami przez niego wytworzonymi, mówimy najczęściej o przestrzeni kulturowej, która poprzez zapewnienie warunków do życia jednostki i zbiorowości jest także jego przestrzenią egzystencjonalną ${ }^{4}$.

\footnotetext{
R. Arnheim, Dynamika formy architektonicznej, Wydawnictwo Officyna s.c. Łódź 2016 s. 16.

Ibidem, s. 17.

Ibidem, s. 20.

4 Pojęcie przestrzeni egzystencjonalnej wprowadził: Ch. Norberg-Schultz, Existencia, espacio y arquitectura. Barcelona 1975, a w kontekście dziedzictwa wyjaśniłem to pojęcie w : A. Kadłuczka, Conservatio est continua creatio" - czyli doktryna ochrony dziedzictwa jako komponentu przestrzeni egzystencjonalnej (Conservatio est continua creatio" : or the doctrine of heritage protection as a component of existential space), Wiadomości Konserwatorskie (Warszawa). Nr 44 (2015), s. 69-77.
} 
Jest ona zdominowana przez przestrzeń publiczną, czyli tę część przestrzeni egzystencjonalnej, gdzie realizuje się określona cywilizacja, rozumiana jako „metoda ustroju życia zbiorowego" . Przestrzeń indywidualna czy inaczej mówiąc „intymna” jest domeną życia jednostkowego, wewnętrznego.

Jest więc przestrzeń publiczna areną naszej zewnętrznej aktywności zawodowej, kulturalnej i wspólnotowej, oraz ściśle zintegrowanej z tą aktywnością komunikacji społecznej określanej jako proces wytwarzania, przekształcania i przekazywania informacji pomiędzy jednostkami, grupami społecznymi i jej zorganizowanymi strukturami. Procesy komunikowania społecznego prowadzą do dynamicznego pozyskiwania, rozwijania, modyfikacji lub weryfikacji wiedzy, postaw i zachowań w kierunku zgodnym z wartościami i interesami akceptowanymi przez określoną cywilizację.

$\mathrm{W}$ polskim prawodawstwie pojęcie przestrzeni publicznej zostało zdefiniowane w ustawie o planowaniu i zagospodarowaniu przestrzennym jako obszar „o szczególnym znaczeniu dla zaspakajania potrzeb mieszkańców, poprawy jakości ich życia i sprzyjajacy nawiąywaniu kontaktów spolecznych ze względu na jego polożenie oraz cechy funkcjonalno-przestrzenne".

Przestrzeń publiczna jest w pierwszym rzędzie domeną planowania przestrzennego, urbanistyki, architektury i ochrony dziedzictwa, ale ze względu na fakt, że jest to miejsce w którym stale odbywa się komunikacja społeczna, stała się ona przedmiotem badań także nauk z zakresu socjologii społecznej, percepcji, psychologii i filozofii przestrzeni.

\section{Muzealizacja a new museology i ecomuseum}

Dotykamy tu zagadnienia nowego zupełnie zjawiska, które niemiecki filozof Hermann Lübbe nazywa muzealizacja mając na myśli niezwykły, stale wzrastający popyt na muzea i zarazem wzrost ich społecznego oddziaływania, miedzy innymi dzięki profesjonalizacji praktyki muzealniczej i szerokim stosowaniu nowych technik ekspozycyjnych ${ }^{6}$.

Rewolucję we współczesnym muzealnictwie na początku lat 70-tych XX wieku wywołała teoria new museology i jej produkt w formie ecomuseum, który miał być reakcją świata intelektualnego na głębokie zmiany zachodzące w społeczeństwie i jego kulturze i próbą stworzenia systemu kontroli, czy wręcz sterowania transformacjami w taki sposób, aby zapobiegać destrukcji dziedzictwa kulturowego i naturalnego i wykorzystać je zarazem jako potężny potencjał w zrównoważonym rozwoju społeczeństwa.

Nie ulega wątpliwości, że muzealizacja jest rezultatem zmiany paradygmatu muzeum jaką zaproponowała filozofia new museology realizowana przez rozpowszechniający się szeroko nowy model muzeum „społecznego"- ecomuseum?

\footnotetext{
F. Konieczny, O wielości cywilizacji, Wyd. Capital 2015.

${ }^{6}$ H. Lübbe, Muzealizacja. O powiąanie naszej teraźniejszości z przeszłościa, w: Estetyka w świecie 3, wybór tekstów pod red. M. Gołaszewskiej, Uniwersytet Jagielloński, Kraków 1991.

7 Wg Petera Daviesa (P. Davies, Ecomuseums: a sense of place, Leicester University Press, 1999) ecomuseum jest formą ochrony dziedzictwa $\mathrm{z}$ akcentem położonym na jego profesjonalną interpretację i racjonalne zarządzanie. Jest także koncepcją diametralnie odmienną od tradycyjnego muzeum, którego architektoniczna forma chroni kolekcję dzieł sztuki i reglamentuje dostęp do nich - koncepcją zakładającą pełną otwartość i dostępność kolekcji dziedzictwa poprzez wzmocnioną relację pomiędzy ecomuseum jako instytucją, a otoczeniem społecznym oraz środowiskiem kulturowym i naturalnym. Atrakcyjna także jako produkt turystyczny oferta ecomuseum udostępnia nie tylko kulturowe artefakty z obszaru sztuki, architektury, czy archeologii, ale także zasoby terytorium geograficznego, dziedzictwa, pamięci i ludzkiej populacji, która odpowiednio ukształtowana i sterowana przez liderów lokalnych społeczności staje się gwarancją osiągnięcia celów zrównoważonego rozwoju.
} 
Jak komentuje refleksje Lübbego Bartosz Korzeniowski, muzealizacja nie ogranicza się tylko do samych muzeów identyfikowanych z instytucją zarządzającą budynkami, które „przestały kojarzyć się z przechowywaniem zakurzonych reliktów ery przedindustrialnej, a staty się atrakcjami dla szerokich mas ludności"s, ale zwraca uwagę na szersze widzenie zjawiska przez niemieckiego uczonego, który dostrzega „muzealizowanie całych krajobrazów kulturowych, osiedli mieszkaniowych wraz z ich mieszkańcami"9.

Rzeczywiście, nie tylko w Europie, ale także w Polsce jest zauważalna postępująca muzealizacja środowiska kulturowego wyrażająca się w „gwaltownym przyroście muzeów $w$ świecie współczesnym $i$ we wzroście ich społecznej roli" ${ }^{10}$. Jest to nie tylko rezultat wzrostu zapotrzebowania na kulturę wynikającego z wykształcenia i poziomu intelektualnego społeczeństwa, ale także wynik ,uboczny” coraz szerszej modernizacji infrastruktury komunalnej czy industrialnej w postaci nowych odkryć archeologicznych i atrakcyjnego zagospodarowywania ich rezultatów. (rys. 1, 2, 3, 4)

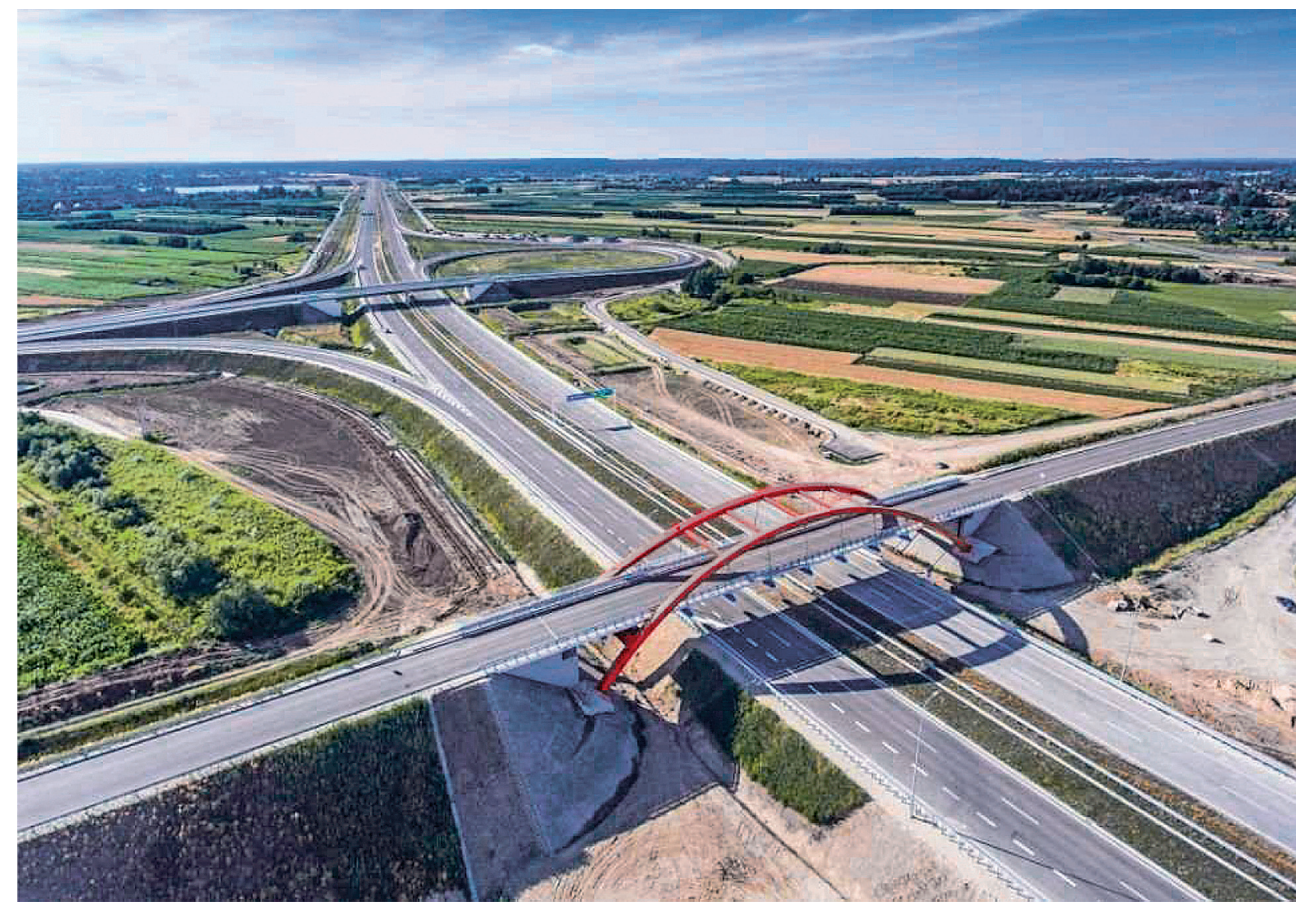

Rys. 1. Autostrada A4 przebiegająca przez tereny historycznej małopolski na odcinku Kraków-Korczowa której budowę poprzedziły badania archeologiczne stała się źródłem rewolucyjnych zmian w wiedzy o przeszłości tego obszaru

8 B. Korzeniewski, Muzealizacja a późnonowoczesna przemiana stosunku do przeszłości, w: Kultura współczesna nr 2/2004, s. 25.

9 Ibidem, s. 25.

${ }^{10}$ B. Korzeniewski, O sposobach obchodzenia się z reliktami przeszłości, w: Sensus Historiae, vol. VI, 2012/1, s. $35-47$. 


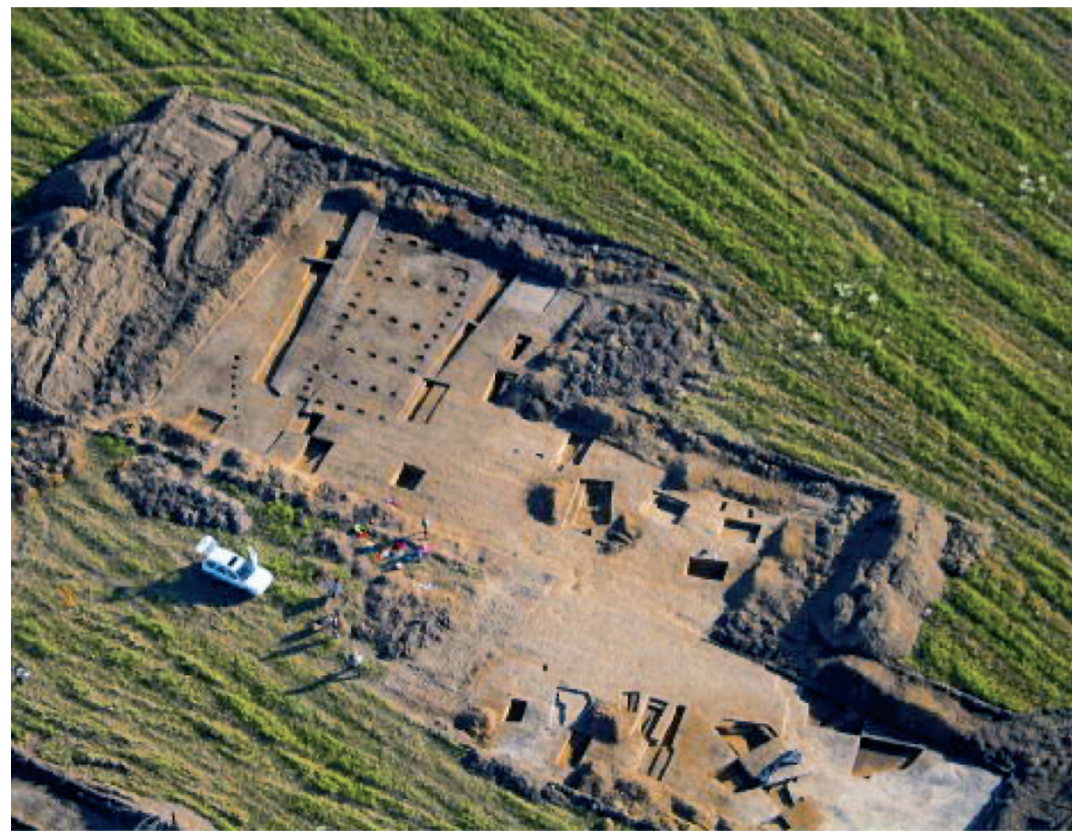

Rys. 2. Stanowisko archeologiczne na trasie autostrady A4 w rejonie Wieliczki

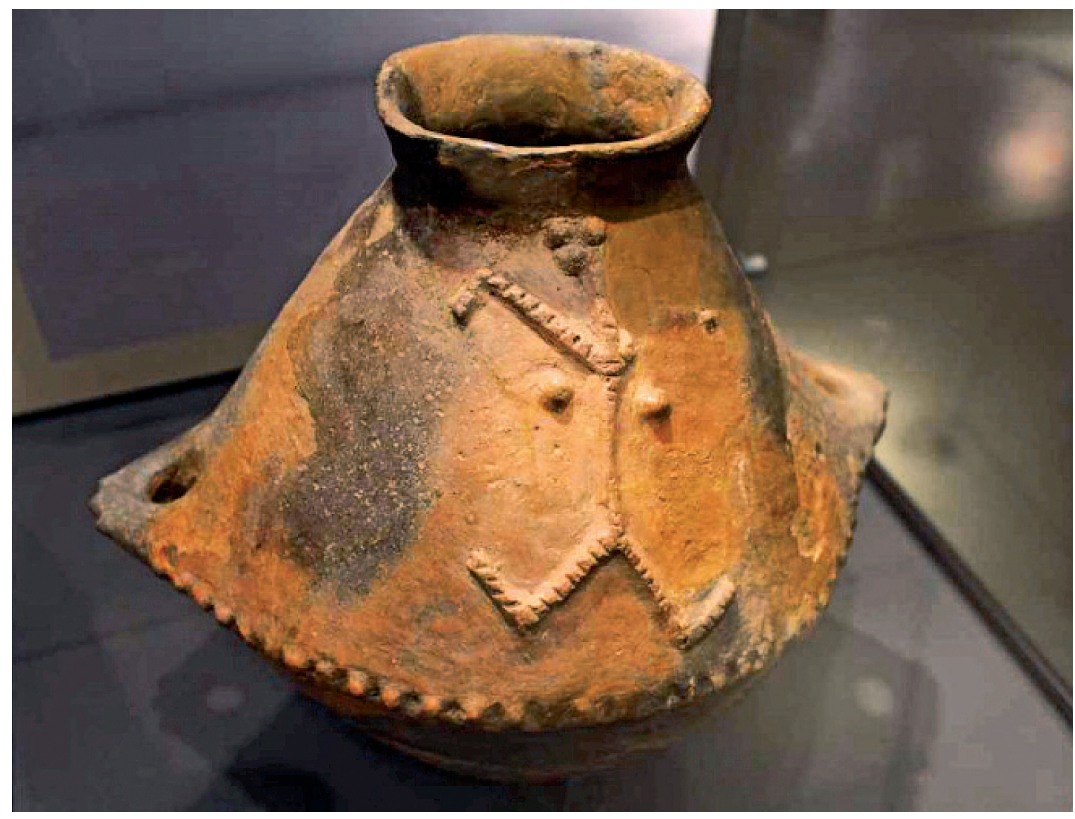

Rys. 3. Amfora z symbolicznym wizerunkiem kobiety datowana na 4,5 tysiąca lat p.n.e., znaleziona na terenie budowy autostrady A4 na Odcinku Rzeszów-Jarosław 


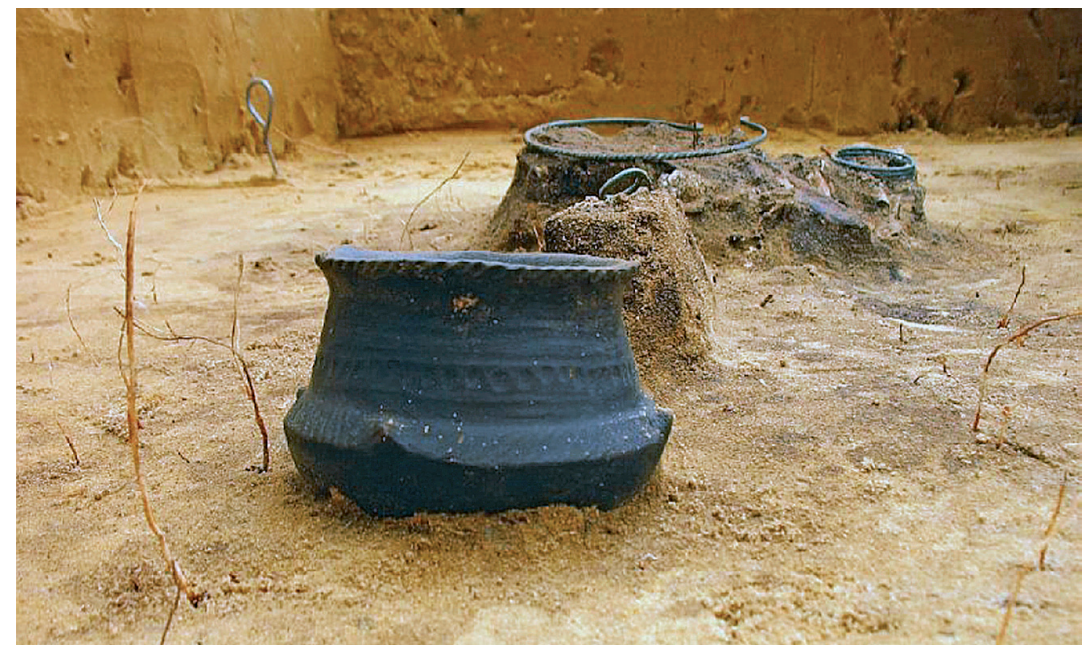

Rys. 4. Amfory znaleziona na cmentarzysku kultury łużyckiej na budowie autostrady A4 koło Kokotowa w rejonie Wieliczki, datowane na VII-V w. p.n.e.

Biorąc pod uwagę, że pojęcie „środowisko kulturowe” ma wymiar niematerialny i materialny zarazem, warto zauważyć, że muzealizacja w dużej mierze dotyczy właśnie przestrzeni publicznej, a polega na lokowaniu w niej nie tylko obiektów sensu stricto muzealnych, quasi muzealnych, czy w ogóle obiektów publicznych: często centrów kultury projektowanych z założenia jako struktury funkcjonalnie hybrydowe przystosowane także do okazjonalnej prezentacji nowości z przeszłości - pomieszczenia kuluarów Stadionu Narodowego w Warszawie były np. wykorzystane w 2016 roku do prezentacji wystawy Muzem Archeologicznego Herkulanum (Rys. 5) - wreszcie kreowanych intencjonalnie muzealizacji miejsc historycznych dedykowanych wyłącznie nowościom z przeszłości, czyli odzyskiwanym artefaktom pochodzącym z przeszłości. Wszystkie te formy muzealizacji naszej przestrzeni kulturowej coraz liczniej ,zasiedlają” tę przestrzeń, integrując elementy profanum i sacrum.

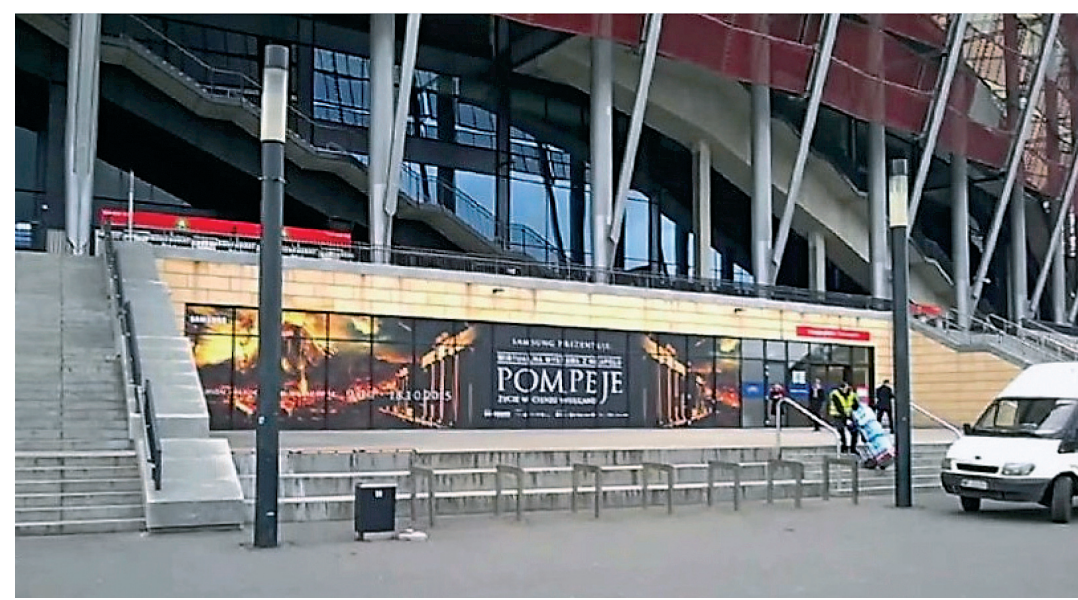

Rys. 5. Stadion narodowy w Warszawie jako miejsce prezentacji wystawy Wirtualne Muzeum Herkulanum (MAV - Museo Archeologico Virtuale, Ercolano) 
Zwróćmy również uwagę, że owa integracja sacrum i profanum dotknęła także klasyczną formułę muzeum jako świątyni artystycznych kolekcji, które przestaje być przestrzenią jej ekspozycji i elitarnej kontemplacji, ale staje się teatrem dla publiczności, przestrzenią widowiska, w której możemy wysłuchać i zobaczyć atrakcyjnie przygotowaną narrację o kolekcji i historii z nią związanych bez konieczności udziału w niej autentycznych artefaktów. Tu coraz większą rolę odgrywają technologie multimedialne, oferujące sugestywnie kreowane przestrzenie wirtualnej rzeczywistości, bądź w pełni „wiarygodne” realne rekonstrukcje oparte na wiedzy pozyskanej w ramach badań archeologii eksperymentalnej ${ }^{11}$, które niekoniecznie dokumentowały, że tak było w konkretnym przypadku, ale że tak mogło być z dużą dozą prawdopodobieństwa. (Muzeum Wirtualne Herkulanum, Muzeum Amfiteatru Rzymskiego w Londynie).

Wobec tych zastrzeżeń natury naukowej tak rozumiana muzealizacja ma swoich przeciwników nie tylko w środowisku konserwatorskim, ale także w obszarze współczesnej humanistyki, która ze sceptycyzmem podchodzi do jej społecznych, czy naukowo-historycznych konsekwencji tego zjawiska. Z drugiej strony nie można nie dostrzegać wpływu muzealizacji na podniesienie poziomu ogólnej wiedzy o przeszłości i generalną zmianę relacji społeczeństw do niej, a także na psychosferę jednostek i zbiorowości, łagodząc skutki zbyt gwałtownych transformacji i rozdźwięk między postępem a tradycją.

Jeszcze w latach 60. ubiegłego stulecia Teodor W. Adorno, niemiecki filozof i socjo$\log ^{12}$ na pytanie o muzealizację wyrażał obawę, że rozumiana tradycyjnie oznacza śmierci sztuki zamkniętej w ,przestrzeni dyscyplinarnej” muzeum, które podobnie jak mauzoleum jest miejscem przechowywania zahibernowanych eksponatów nazywanych dziełami sztuki. Adorno postrzegał je jako ,absolut imitacji” ilustrujący zhierarchizowane stosunki społeczne, zaś muzeum jako strukturę administracyjną potwierdzającą pogląd o zagubieniu w niej estetycznej prawdy sztuki niemożliwej do zrozumienia bez analizy kontekstu.

\footnotetext{
${ }^{11}$ Archeologia eksperymentalna to nowa metoda, która do warsztatu archeologa wprowadziła doświadczenie pozwalające na uprawdopodobnienie stawianych hipotez w odniesieniu do replikacji artefaktów lub procesów ich wytwarzania. Jej głównym celem jest zbieranie materiału porównawczego i rozwijanie wiedzy ogólnej, ułatwiającej interpretację materiału źródłowego i artefaktów pozyskanych w drodze eksploracji badawczej stanowisk archeologicznych. Przez niektórych jest przyjmowana krytycznie ze względu na komercyjny charakter wykorzystywania jej rezultatów i konflikt z fundamentalnymi zasadami ochrony dziedzictwa; szerzej w: A. Kadłuczka, Ochrona Dziedzictwa Architektury i Urbanistyki. Zarys doktryn, teorii i praktyki, Wyd. II PK, Kraków 2018 (w druku), por. także: Experiments Past. Histories of Experimental Archaeology, Edited by Jodi Reeves Flores \& Roeland Paardekooper, Sidestone Press, Leiden 2014.

12 Theodor W. Adorno, właściwe nazwisko: Theodor Ludwig Wiesengrund, (1903-1969) - niemiecki filozof, socjolog, teoretyk muzyki i kompozytor należał do czołowych przedstawicieli kierunku teorii filozofii krytycznej rozwijanego w tzw. „szkole frankfurckiej”, której Adorno był współtwórca; por.: R. Różanowski, Zrozumieć Adorno, w: Dyskurs 9 - Teoria i Historia, Wyd. ASP Wrocław 2012. „, stwierdza, że ,, Idee Adornowskie należa niewatpliwie do najznaczniejszych dokonań wspótczesnej myśli estetycznej. Wlatach sześćdziesiątych i siedemdziesiątych ubiegłego wieku autor Dialektyki negatywnej byt najbardziej wplywowym $w$ Niemczech, obok Heideggera $i$ Gadamera, estetykiem i teoretykiem sztuki. Istotnym argumentem przemawiajacym na jego korzyść było umiejętne powiąanie perspektywy estetycznej z perspektywa społeczna” s. 64 i dalej: ,, W rozdziale zatytułowanym Przemyst kulturalny. Oświecenie jako masowe oszczerstwo napisanej wspólnie z Maxem Horkheimerem Dialektyki oświecenia (1947) Adorno włącza tę analizę wogólniejsze ramy teoretyczne. Nawiązując do Marksa 68 Ryszard Różanowski i Lukácsa, a także Schopenhauera i Nietzschego, w pewnym sensie radykalizując ich myśli, zarysowuje obraz społeczeństwa z totalnie uprzedmiotowionymi stosunkami społecznymi; społeczeństwa, w którym na wszystkich płaszczyznach - społecznej $i$ indywidualnej, $w$ sferze poznania $i w$ dziedzinie moralności - zasada wymuszonej, zewnętrznej jedności (,,tożsamości”) panuje nad momentami jakościowej odrębności (później Adorno będzie mówił o tym, co „,nietożsame”17). Na tym historyczno-filozoficznym i krytycznym gruncie formuluje teze o zagubieniu estetycznej prawdy w przemyśle kulturalnym. Administrowane w nim formy sztuki sa nieprawdziwe, gdyż jedynie odtwarzaja istniejace zhierarchizowane stosunki społeczne, ustanawiaja ,, absolut imitacji”'18. Prawdziwa natomiast nazywa Adorno sztuke, która stosunki społeczne rozpoznaje jako negatywne, wyobcowane i urzeczowione. s. 67-68.
} 
Z pozycji historyczno-filozoficznej jest to krytyka tradycyjnej formuły muzeum rozwijanej w XVIII-XIW wieku, która jedynie fonetycznie nawiązywała do antycznego museionu, ale semantycznie była od niego już bardzo odległa ${ }^{13}$.

Aktualnie, krytyka muzealizacji podjęta głównie przez badaczy francuskich i angielskich ogniskuje się na antyhumanistycznym niebezpieczeństwie „substytucjonalności wartości”, jako rezultatu tempa zmian i ,przyspieszenia historii”, które stwarzają możliwości, a niekiedy nawet potrzebę operowania ,zamiennikami”, które chociaż pozornie zaspakajają potrzeby odbiorcy, są jednak odmienne pod względem pochodzenia i sposobu wytworzenia, a tym samym nośnikiem innych wartości. Realnym skutkiem tego może być zacieranie się i rozmywanie tożsamości jednostki i zbiorowości, utrudnienie a nawet finalne uniemożliwienie ich samoidentyfikacji, stając się potencjalnie niebezpieczeństwem dla przyszłych pokoleń nierozpoznawalnym ${ }^{15}$.

Zastrzeżenia związane z nadmiernym stosowaniem substytucjonalnych wartości dotyczą także współczesnej doktryny konserwatorskiej, a zwłaszcza wartości naukowo-historycznej „rekonstrowanych rzeczywistości”"16, które wypierają „coraz bardziej faktyczną realność rzeczywistości"17 i stają się już nie tyle substytutem ile powszechnie rozumianym atrybutem autentyzmu. (Termy Rzymskie w Carnuntum, Park Archeologiczny w Xanten, muzea archeologiczne limesu rzymskiego na linii Mosela-Ren; Rys. 6, 7)

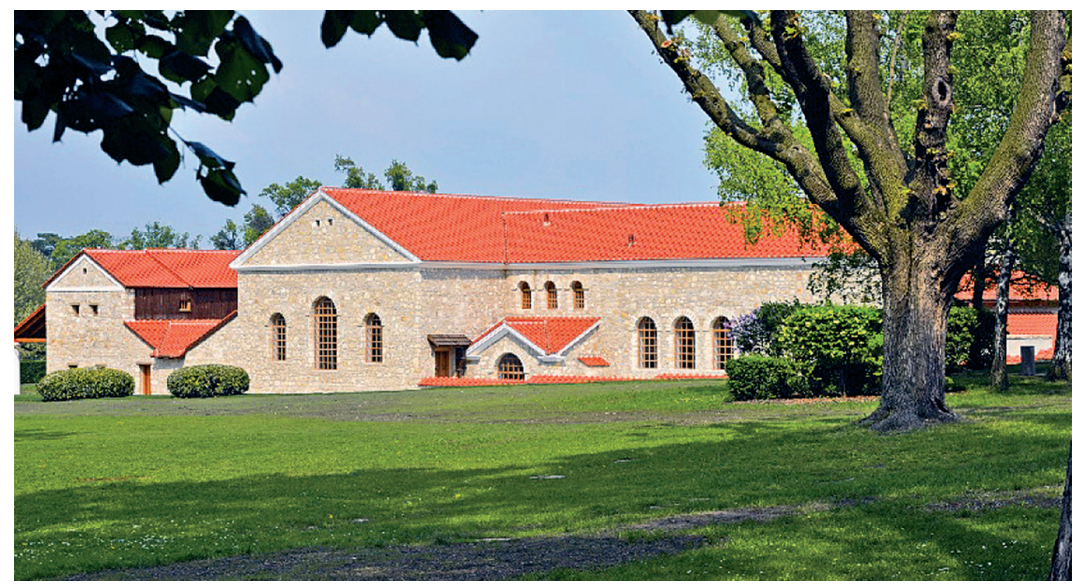

Rys. 6. Park archeologiczny Petronellum-Carnuntum w Austrii, nowo wzniesiony w oparciu o założenia archeologii eksperymentalnej ,,antyczny” budynek term rzymskich

\footnotetext{
${ }^{13}$ Museion, którego archetypem było słynne Muzeum Aleksandryjskie założone ok. 295 p.n.e. przez Ptolemeusza I Sotera, w założeniu i w praktyce, o czym może warto przypomnieć, realizowało zadania starożytnego instytutu naukowego w dziedzinach humanistycznych, jak i ścisłych. Jego główne człony: Biblioteka Aleksandryjska, obserwatorium astronomiczne, oraz ogród botaniczny i zoologiczny uzupełniały budynki mieszczące lektoria, pracownie i laboratoria, ale także przestrzenie publiczne - fora-miejsca dysput naukowych, sporów intelektualnych i wymiany informacji.

${ }^{14}$ D. Hervieu-Leger, Religia jako pamięć, Nomos, Kraków 1999.

15 P. Nora, Czas pamięci, w: „Respublika Nowa”, nr 7, 2001, s. 40; „Nie wiemy, co nasi następcy będa potrzebowali wiedzieć o nas, żeby zrozumieć siebie samych. I ta niezdolność antycypowania przyszłości nakłada na nas obowiazek nabożnego gromadzenia, w sposób trochę niezróżnicowany, wszystkich widzialnych śladów i materialnych znaków, które zaświadcza (być może), czym jesteśmy lub czym się okażemy".

${ }^{16}$ Chodzi tu o współczesne koncepcje parków archeologicznych i rekonstrukcji obiektów w oparciu o doświadczenia ,archeologii eksperymentalnej”, por.: przypis 11.

17 T. Overdick, Landschaft und Museum. Theoretische Überlegungen zur Musealisierung von Landschaft, Museologie Online, 1. Jahrgang Hagen 1999, ss. 1-40, www.hco.hagen.de/museen/m-online.
} 


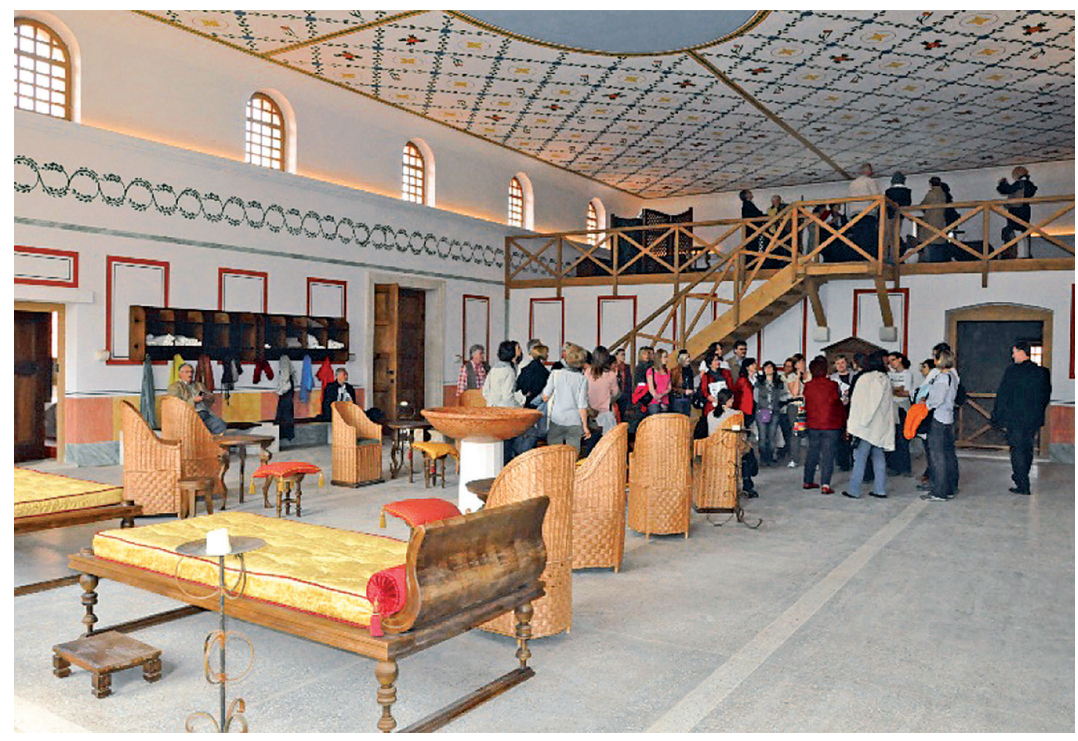

Rys. 7. Park archeologiczny Petronellum-Carnuntum w Austrii, wnętrze „,antycznego” budynku term rzymskich, odbierane przez zwiedzających jako autentyczny „zabytek” (na podstawie sondaży)

Niezależnie od wątpliwości i zastrzeżeń, muzealizacja pozostanie istotnym czynnikiem w kształtowaniu współczesnej przestrzeni publicznej, która jest paradoksalnie przestrzenią „historyczną”, skoro poruszamy się wśród rzeczy już zasiedlających tę przestrzeń, a więc należących do przeszłości, a ich percepcja i relacje pomiędzy tymi rzeczami jest wynikiem doświadczenia możliwego do zaistnienia wyłącznie z perspektywy przemijania czasu.

Doświadczenie pozwala nie tylko na percepcję - poznanie, zdobycie wiedzy, ale także na jej interpretację, retrospekcję, utrzymanie i rozbudowę pamięci: „Niewiedza jest niepamięcią. Poznanie, tj. szukanie wiedzy jest przypominaniem tego co już w sposób niewyraźny wiemy ... W jawiacej się przed nami rzeczy rozpoznajemy wygląd (eidos), który widzieliśmy już wcześniej. Byt rzeczy dany jest dzięki potędze pamięci: ${ }^{18}$. Pamięć jest zatem zapisem doświadczenia bez którego nie jest możliwa kontynuacja bytu - każda kolejna kreacja, także architektoniczna jest budulcem wiedzy na której oparta jest nauka.

\section{Muzealizacja a spoleczeństwo}

$\mathrm{Na}$ tle rozwoju nowego typu muzealnictwa (new museology), a także dynamicznych zmian w mentalności współczesnych społeczeństw obserwujemy nowe zjawisko nazywane przez badaczy muzealizacja przestrzeni, która jako chronologicznie powiązana z retrospekcją przeszłości paradoksalnie prowadzi do zawężania obszarów współczesności. Być może wkraczamy tu w obszar owej zagadki czasu, o której wykładał Hans Georg Gadaemer ${ }^{19}$, z którą można by powiązać fenomen „kurczenia się teraźniejszości”, co oznacza, że „wraz ze zwiększeniem ilości nowości następuje zarazem wzrost tego co przestarzałe, a im bardziej

\footnotetext{
${ }^{18}$ D. R. Sobota, Źródła i inspiracje Hedegderowskiego pytania o bycie, Tom „Neokantyzm i Fenomenologia”, Wyd. Fundacja Kultury Yakiza, Bydgoszcz 2012, s. 435.

${ }^{19}$ Zagadnienie to zostanie szerzej omówione w rozdziale XII.
} 
dynamicznie przebiega ewolucja kultury, tym większy staje się relatywny udziat tego dziedzictwa kultury"20.

Autor tej konstatacji cytowany już Hermann Lübbe, pisząc o ,zwiększeniu ilości nowo$s ́ c i$ ” ma oczywiście na myśli także nowości z przeszłości, co w kontekście rozwoju stanowisk archeologicznych, ten proces można zilustrować rezultatami badań archeologicznych jakie towarzyszyły i nadal towarzyszą inwestycjom w systemach infrastruktury komunikacyjnej, które w Europie i w Polsce są bez wątpienia imponujące.

Są one rezultatem dynamicznego rozwój naszej cywilizacji, wzrostu demograficznego, urbanizacji i industrializacji i tym samym ingerują w zastaną przestrzeń kulturową i naturalną, w tym także w jej historyczną stratygrafię. (Muzeum Podziemne Rynku Krakowskiego ${ }^{21}$. Rys. 8, 9, 10, 11).

Prowadzone na obszarze wielu inwestycji obligatoryjne badania naukowe przyniosły odkrycia ważne nie tylko dla nauk historycznych, ale także rozwoju regionalnego, dla którego stały się stymulatorem. (Słoniowice, Rzeszów, Szczepanowice, Nowy Sącz). Są także dowodem wzrastającej rola społeczeństwa obywatelskiego w decyzjach i zarządzaniu o kierunkach rozwoju, a także w dostępie do wiedzy i sposobie jej wykorzystania z korzyścią dla lokalnych zbiorowości. Tym samym w sposób istotny zmieniają ich stosunek do przeszłości, przenosząc akcenty z kontemplacji i kultywacji dziedzictwa na jego kreatywne, twórcze wykorzystanie jako kapitału i komponentu w rozwoju cywilizacji współczesnej.
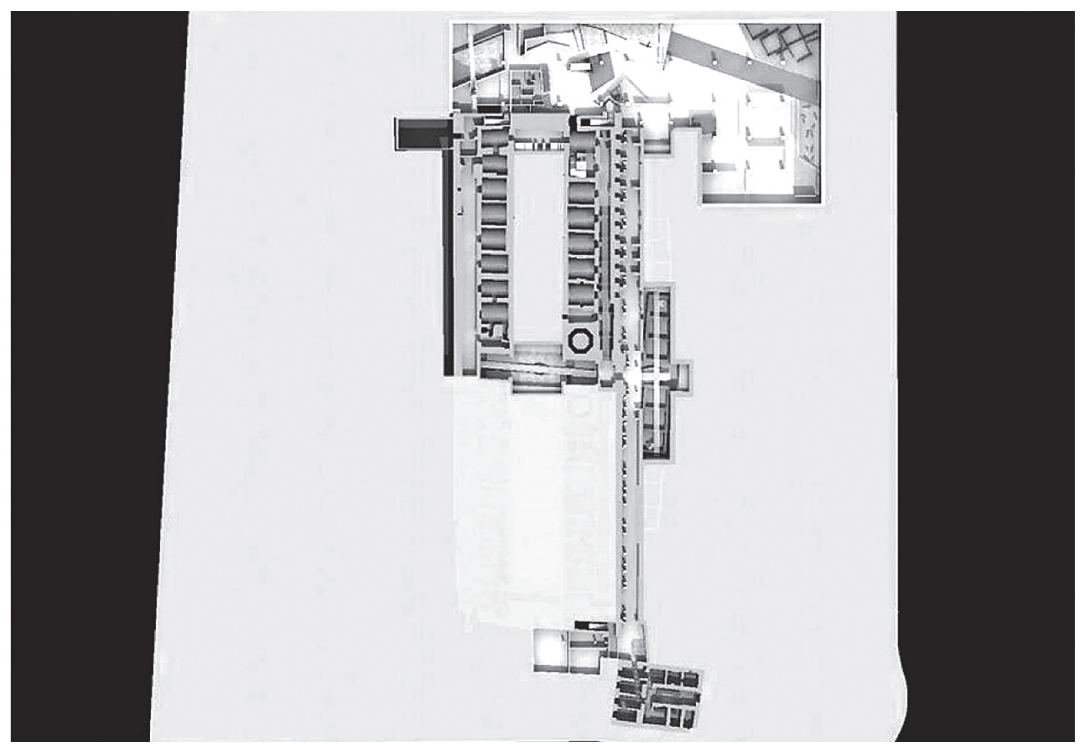

Rys. 8. Muzeum Podziemne Rynku Krakowskiego, model komputerowy finalnej wersji ekspozycji o łącznej powierzchni 6,5 tyś. $\mathrm{m}^{2}$ (z pomieszczeniami recepcyjnymi i technicznymi)

\footnotetext{
${ }^{20}$ H. Lübbe, Doświadczenia czasu jako czynnik ewolucji kulturowej, w: Studia z filozofii niemieckiej, T. 2, Wyd. UMK Toruń 1996.

${ }^{21}$ Koncepcja, projekt budowlany i wykonawczy Muzeum Podziemnego Rynku, oraz projekt architektoniczny ekspozycji: Andrzej Kadłuczka z zespołem Archeconu, projekt plastyczny scenariusza ekspozycji: Mieczysław Bielawski, Marcin Pietuch, Tomasz Salwierz, opracowanie merytoryczne scenariusza: Cezary Buśko, Sławomir Dryja, Wojciech Głowa, Stanisław Sławiński, technologia i multimedia: Agata Sitko i Tomasz Zalewski $\mathrm{z}$ zespołem TRIAS.
} 


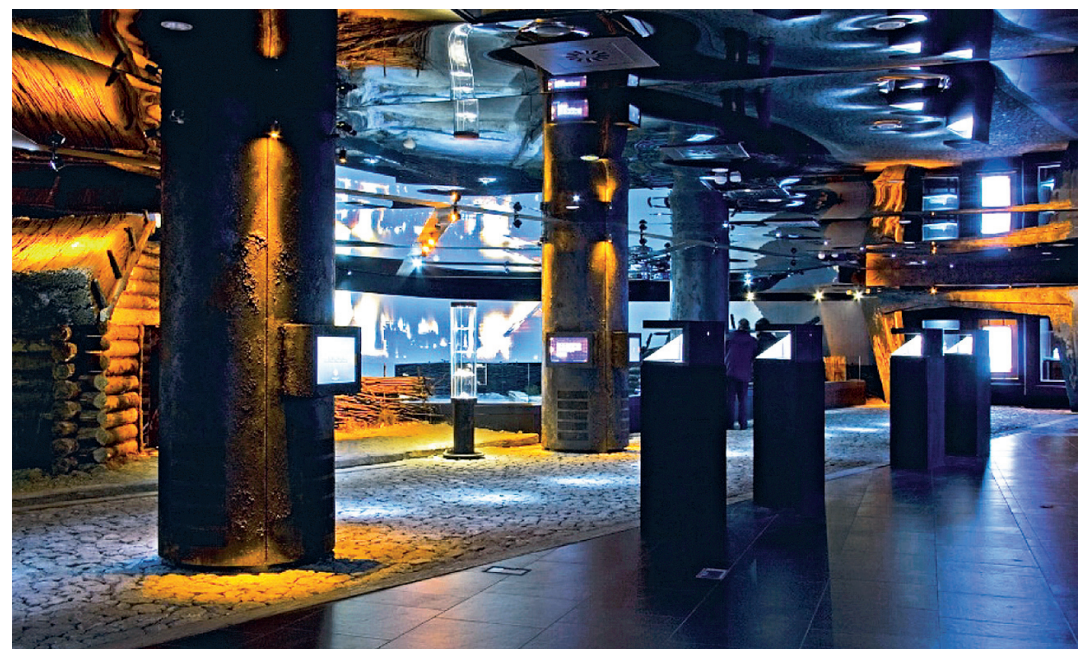

Rys. 9. Muzeum Podziemne Rynku Krakowskiego, główna sala ekspozycyjna

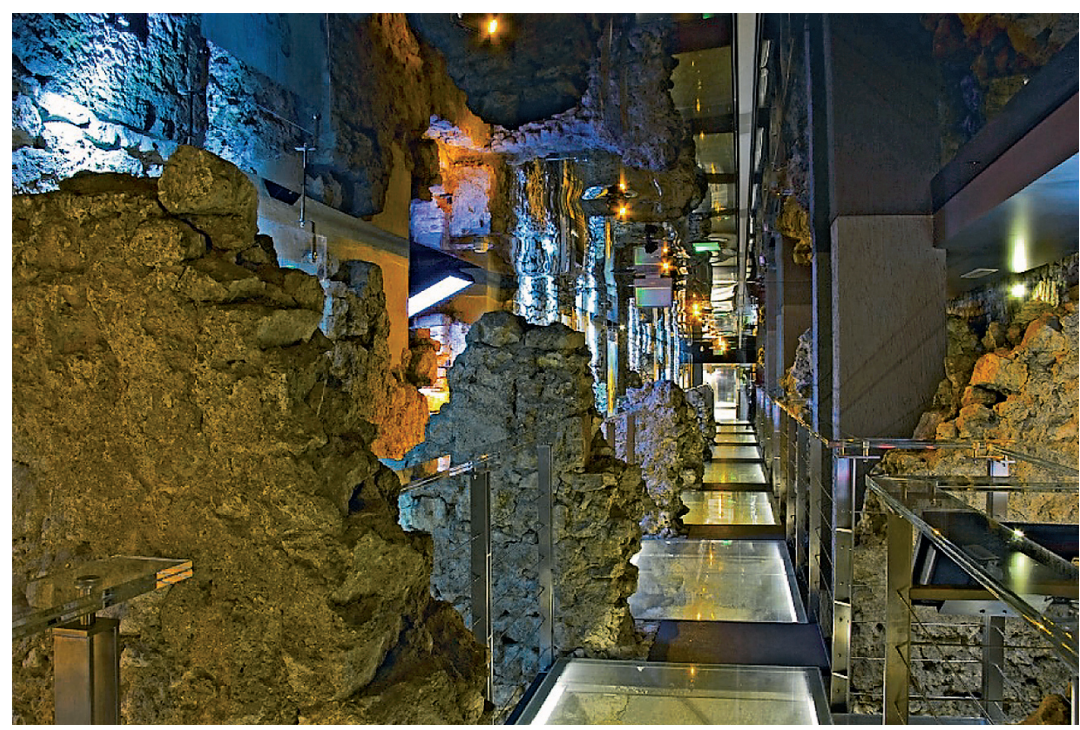

Rys. 10. Muzeum Podziemne Rynku Krakowskiego, galeria ekspozycyjna, pasaż o długości 100 m, poprowadzony wzdłuż komór zachodniego traktu Kramów Bogatych do wnętrz Wagi Wielkiej

Badania na obszarach inwestycji uzupełniają wiedzę o przeszłości, która jest zapisywana w formie Archeologicznego Zdjęcia Polski (AZP). Realizowane od 1978 roku przedsięwzięcie poszukiwania, identyfikowania i dokumentowania stanowisk archeologicznych ma na celu ochronę tych stanowisk i gromadzenie informacji zwłaszcza pod kątem ich wykorzystania w kontekście planowanych inwestycji ${ }^{22}$.

\footnotetext{
${ }^{22}$ Według danych Narodowego Instytutu Dziedzictwa, zarządzającym zbiorem AZP, zarejestrowanych jest obecnie 435000 stanowisk archeologicznych na terenie Polski.
} 


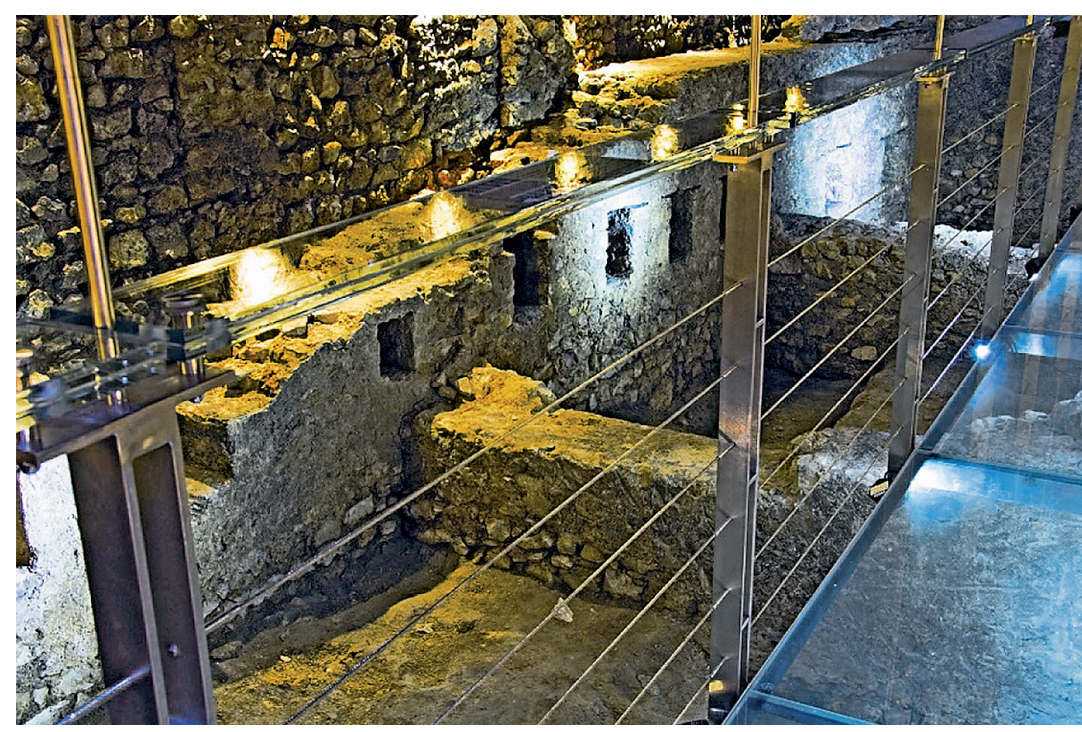

Rys. 11. Muzeum Podziemne Rynku Krakowskiego, galeria ekspozycyjna nad pomieszczeniami pierwszych, lokacyjnych kramów kamiennych z II połowy XIII wieku

W badaniach humanistycznych i społecznych zwraca się uwagę, że owa muzealizacja przestrzeni, będąca reakcją na potrzeby modernizacyjne i poszukująca przywrócenia wagi odniesienia do przeszłości, oraz spełniająca funkcje równoważące wobec rozwoju cywilizacji, oznacza de facto rewaloryzację całych krajobrazów kulturowych i restaurację starych, niekoniecznie artystycznie cennych budynków i budowli, ale posiadających „wartość starożytniczą", wreszcie - rosnący dynamicznie popyt na relikty historii naturalnej ${ }^{23}$.

Jak zauważył Bartosz Korzeniowski analizując zagadnienie przestrzeni historycznej, stając na stanowisku, że materialne relikty historyczne (artefakty) mają istotne znaczenie w badaniach nad pamięcią przeszłości. Co więcej, są budulcem dla tworzenia miejsc pamię$c i$, nawet wtedy, gdy „mamy do czynienia z poddaniem tychże przedmiotów procesowi daleko idacej symbolizacji ... i dalej ... Im szybciej następuja zmiany w społeczeństwach późnonowoczesnych, tym więcej funkcji przypisuje się przedmiotom pochodzacym z przeszłości. Tendencja do ich obsadzania $w$ roli dowodów poświadczajacych realne istnienie przeszłości oraz namiastki bezpośredniego z nia kontaktu w ramach „,miejsc pamięci” prawdopodobnie zyska jeszcze na sile"24.

Mówiąc o owym budulcu miejsc historycznych, który tu nazywam artefaktami, jak to wielokrotnie tu powtarzano, tworzą one zasób kulturowy, którego wartość w całym wymiarze jego autentyczności ma kluczowe znaczenie dla społecznego odbioru. Powołując się na Lübbego, Korzeniowski uważa, że takie właśnie artefakty - „przedmioty pochodzace z przeszłości" należą do tego typu zasobów, które w przeciwieństwie do wciąż zmieniającego się zasobu nowości, swą trwałość w pamięci społecznej zawdzięczają ponadczasowym wartościom.

\footnotetext{
${ }^{23}$ H. Lübbe, ibidem, por także: A. Szpociński, Tworzenie „przestrzeni historycznej” jako odpowiedź na nostalgię, w: Kultura współczesna, nr 1 (2004), s. 58-68 oraz idem, Autentyczność przeszłości jako problem kultury współczesnej, w: A. Szpociński (red.), Wobec przeszłości. Pamięć przeszłości jako element kultury współczesnej, Narodowe Centrum Kultury, Warszawa 2005, s. 292-303.

${ }^{24}$ B. Korzeniewski, op. cit, s. 45 i dalsze.
} 
Ten ponadczasowy certyfikat wartości dziedzictwa daje zarazem podstawę do społecznej akceptacji muzealizacji przestrzeni kulturowej we wszystkich jej typach, formach i przejawach.

Reasumując, możemy przyjąć jak najogólniej, że muzealizacja przestrzeni publicznej jest formą ochrony dziedzictwa kulturowego, ale rozszerzając pole obserwacji jest ona także wskaźnikiem jakości przestrzeni w sensie jej ładu i estetyki, a także wartością kulturową pochodzącą z przeszłości, ale istotną dla współczesnego rozwoju i integracji społecznej.

\title{
Musealization of public space as a form of the presence of cultural heritage in contemporary world
}

\author{
Andrzej Kadłuczka \\ Faculty of Architecture, Cracow University of Technology, Cracow, Poland
}

\begin{abstract}
The article discusses the new phenomenon of public space musealization, which does not only mean sociologists perceive dynamically growing social demand for innovation and attractively shaped museums, historical heritage centers, but also an ever-wider, direct - "physical" presence of this heritage in the life of contemporary man. This presence is generated by progress and development of investments carried out in historical areas, which become the source of an increasing number of structures and artefacts coming from the past "settling" public space in the form of it or more successful exhibits reconstructing historical reality and presenting knowledge about the past.
\end{abstract}

Keywords: space, public space, cultural heritage, museum, ecomuseum, musealization. 